\title{
Uroporphyrinogen Decarboxylase
}

National Cancer Institute

\section{Source}

National Cancer Institute. Uroporphyrinogen Decarboxylase. NCI Thesaurus. Code C95569.

Uroporphyrinogen decarboxylase (367 aa, $41 \mathrm{kDa}$ ) is encoded by the human UROD gene. This protein is involved in the biosynthesis of heme groups. 